\title{
The use of an anaerobic incubator for the isolation of anaerobes from clinical samples
}

\author{
PL BERRY, E TAYLOR, I PHILLIPS \\ From the Department of Microbiology, St Thomas's Hospital Medical School, London SE1 7EH
}

SUMMARY An anaerobic incubator was compared with a standard jar system for the isolation of anaerobes from clinical material. Seventy specimens were selected as likely to yield anaerobes: 342 different anaerobes were isolated in the incubator and 347 in anaerobic jars. These included Bacteroides spp (43\%), Peptococcus spp (26\%), Peptostreptococcus spp (13\%), Veillonella spp (7\%), Fusobacterium spp (7\%), Clostridium spp (2\%) and miscellaneous Gram-positive nonsporing bacilli $(2 \%)$. Differences in isolation rates for each system were inconsistent and minor.

Sixteen anaerobes were chosen for quantitative tests at the beginning and end of the study period. Miles and Misra counts showed a slight advantage of the incubator for $F$ nucleatum, but no difference for $B$ fragilis, $B$ thetaiotaomicron, $B$ uniformis, $B$ bivius, $B$ corrodens, $F$ mortiferum, $P$ s anaerobius, $\boldsymbol{P}$ prevotii or Propionibacterium acnes. In almost all cases, colonies in anaerobic jars were slightly larger than those in the incubator. Disc antibiotic sensitivity tests gave the same results in each system, at the beginning and end of the study period.

The anaerobic incubator provides an effective means of isolation of anaerobes in a clinical laboratory. However, several design features of the prototype would require change if the system were introduced.

Increased awareness in recent years of the role of anaerobic bacteria in common infections has led to demands for the isolation of these organisms in the diagnostic laboratory. ${ }^{1-3}$ Most of the work can be carried out with anaerobic jars, ${ }^{4-6}$ but these require care and skill in use. Jars are often set up when there are sufficient plates to fill them, leading to delays in the critical early phase of incubation. Furthermore, diagnostic work in larger laboratories is usually divided into sections, with each having its own jars: this creates a problem when incubator space is limited. There is thus a possible need for an anaerobic incubator into which plates can be placed immediately they are inoculated and from which they can be removed without rendering the whole system aerobic. We have assessed the performance of such an incubator in comparison with that of anaerobic jars.

\section{Material and methods}

ANAEROBIC SYSTEMS

The anaerobic jars were converted six- or eight-litre pressure cookers. ${ }^{7}$ Plates were placed in the jar

Accepted for publication 16 February 1982 along with two catalyst sachets each containing about $5 \mathrm{~g}$ catalyst previously heated to $160^{\circ} \mathrm{C} .^{8}$ The jars were evacuated with an Edwards type 2 vacuum pump to a reading of $-760 \mathrm{mmHg}$, on a Gallenkamp pressure gauge and filled with $10 \%$ hydrogen, $10 \% \mathrm{CO}_{2}$ and $80 \%$ nitrogen.

The anaerobic incubator was a prototype produced by GV Planer Ltd. in co-operation with the Department of Health and Social Security. It consisted of a chamber of internal dimensions $61 \mathrm{~cm} \times$ $63.5 \mathrm{~cm} \times 35.5 \mathrm{~cm}$, with a $62 \mathrm{~cm} \times 32 \mathrm{~cm}$ window containing a $15.3 \mathrm{~cm}$ glove port fitted with a $70 \mathrm{~cm}$ size 9 neoprene glove (Hanfare Protective Clothing Ltd.). Inside the chamber were a $51 \mathrm{~cm}$ diameter turntable with space for 10 stacks of Petri dishes and a $23 \mathrm{~cm} \times 28 \mathrm{~cm}$ shelf $25.5 \mathrm{~cm}$ above the base. Cultures were placed in the incubator via a $25.5 \mathrm{~cm}$ $\times 20.5 \mathrm{~cm} \times 16.5 \mathrm{~cm}$ (internal dimensions) transfer port with a $51 \mathrm{~cm}$ transfer arm, an inner door $(20.5$ $\mathrm{cm} \times 16.5 \mathrm{~cm})$ and an outer door $(17 \mathrm{~cm} \times 13.8 \mathrm{~cm})$ with a window. Two containers, containing approximately $200 \mathrm{~g}$ of Engelhard Deoxo " $\mathrm{D}$ " palladium catalyst pellets (Don Whitley Scientific) were used in the incubator, and the catalyst containers and silica gel were recycled in the same manner as jar catalyst. An Edwards type 2 Vacuum pump (British Oxygen 1158 
Company) was used for initial evacuation, and the incubator was rendered anaerobic by flushing with $10 \%$ hydrogen, $10 \% \mathrm{CO}_{2}$ and $80 \%$ nitrogen.

A Forma Scientific System model 1024 anaerobic work station was used for incubation of identification tests, including API-20A strips.

\section{ISOLATION OF ANAEROBES FROM CLINICAL} SPECIMENS

Specimens of pus were collected from patients in St Thomas' Hospital between July 1979 and May 1980 and transported immediately to the laboratory either in 25-ml bottles or on serum-coated swabs. They were examined for brick-red fluorescence in ultra-violet light ${ }^{10}$ and the odour noted. A Gram stain was performed and whenever possible unextracted, underivatised pus was examined for the presence of volatile fatty acids in a Pye Unicam GCD Chromatograph. ${ }^{10}$ Only specimens likely to contain anaerobes on the basis of these preliminary investigations were included in the study.

Specimens were inoculated on blood-agar (Columbia agar, Oxoid CM331, plus 10\% defibrinated horse blood) and on our own selective medium consisting of brain heart infusion agar (Oxoid CM375) plus $0.05 \%$ cysteine hydrochloride, $1 \%$ vitamin $\mathrm{K}$-haemin solution, $0.5 \%$ yeast extract, $10 \mu \mathrm{g} / \mathrm{ml}$ nalidixic acid (Winthrop), $7.5 \%$ whole defibrinated horse blood and $2.5 \%$ lysed (by freezing and thawing) horse blood.

The plates were incubated in the two systems and aerobically. A stock culture of Pseudomonas aeruginosa inoculated on Simmon's citrate agar (Oxoid CM155) was used as a biological indicator of anaerobiosis in each of the systems. ${ }^{7}$ After $48 \mathrm{~h}$, cultures were removed for observations on colony morphology, Gram staining, and subculture aerobically and anaerobically of probable anaerobes. All these manipulations were performed on the bench under normal atmospheric conditions. Identification of anaerobes was based on the methods set out in the VPI Manual ${ }^{11}$ and included in addition to Gram staining and observation of colonial morphology, determination of antibiotic susceptibility, gas-liquid chromatography and the range of biochemical tests included in API-20A strips, the latter used only for bacilli.

COLONY COUNTS AND SIZES OF PURE CULTURES A suspension of a $24-48 \mathrm{~h}$ blood agar culture of the isolates listed in Table 3 was made in saline to give a turbidity of 5 International Opacity Standard Units (Wellcome opacity tubes). Serial five- and tenfold dilutions of this suspension were prepared, and $\mathbf{0 . 2}$ $\mathrm{ml}$ of each inoculated on quadrants of blood agar plates, incubated within $20 \mathrm{~min}$ in parallel in the incubator and jar systems for 48-72 h. Colonies were then counted in cultures from appropriate dilutions and sizes of 24 discrete colonies measured with a microscope with graduated eyepieces.

\section{$\mathrm{pH}$}

The surface $\mathrm{pH}$ of inoculated and uninoculated, incubated and unincubated $10 \%$ horse blood agar plates was measured with an Ingold e07 403-30-M3 surface electrode ( $3 \mathrm{~mm}$ separation) and a Pye model $78 \mathrm{pH}$ meter, with an accuracy $0.1 \mathrm{pH}$ units. Readings were made after 2 min contact and recorded as averages for three readings.

\section{ANTIBIOTIC SENSITIVITY}

For disc sensitivity tests, the inoculum was prepared as for counts with a density of about $10^{6} \mathrm{CFU} / \mathrm{ml}$ and inoculated on $10 \%$ horse blood agar plates. Discs (Mast Laboratories) of clindamycin $(2 \mu \mathrm{g})$, metronidazole $(2.5 \mu \mathrm{g})$, erythromycin $(60 \mu \mathrm{g})$, tetracycline $(25 \mu \mathrm{g})$, ampicillin $(10 \mu \mathrm{g})$ and chloramphenicol $(10 \mu \mathrm{g})$ were added and plates incubated in parallel in the two systems. After $48 \mathrm{~h}$ zone radii were measured. Two sets of investigations were carried out, the second six months after the first, on a total of 28 isolates of 18 different species of Grampositive and Gram-negative anaerobes.

\section{Results}

Of the pus samples examined, 70 were studied in detail: the overall results are shown in Table 1. A single anaerobe in pure culture was isolated from only one specimen, mixed anaerobes from a quarter of the specimens, and mixed aerobes and anaerobes from the rest.

Control cultures of Ps aeruginosa in the entry port grew after 24 hours indicating a degree of failure of anaerobiosis. Cultures within the chamber remained negative, indicating satisfactory anaerobiosis, provided the chamber was used regularly, but growth was obtained when the incubator was left over a weekend, indicating that oxygen was gaining entry. Regular recharging by regular use was thus essential with this prototype incubator.

Cultures in the incubator yielded 342 anaerobes and those in jars yielded 347. Detailed results are shown in Table 2 . There are few differences between the two systems, usually explicable in terms of failure to detect organisms in complex mixtures, failure to detect pairs of organisms that eventually were found to vary in antimicrobial susceptibility, or of failure to proceed with the identification of one of a pair of organisms initially thought to be the same.

Table 3 lists the results of comparisons of yields of organisms in pure culture. There was a significant 
Table 1 Specimens investigated and overall isolation rates of aerobes and anaerobes

\begin{tabular}{|c|c|c|c|}
\hline \multirow[t]{2}{*}{ Specimen } & \multirow{2}{*}{$\begin{array}{l}\text { No of } \\
\text { specimens }\end{array}$} & \multicolumn{2}{|l|}{ No yielding: } \\
\hline & & $\begin{array}{l}\text { Aerobes and } \\
\text { anaerobes }\end{array}$ & $\begin{array}{l}\text { Anaerobes } \\
\text { only }\end{array}$ \\
\hline \multicolumn{4}{|l|}{ Perianal } \\
\hline \multicolumn{4}{|l|}{ Buttock } \\
\hline $\begin{array}{l}\text { Ischiorectal } \\
\text { Perineal }\end{array}$ & 20 & 15 & 5 \\
\hline \\
\hline \multicolumn{4}{|l|}{ Abdominal wall } \\
\hline Liver & 17 & 16 & 1 \\
\hline $\begin{array}{l}\text { Peritoneum } \\
\text { Subphrenic }\end{array}$ & & & \\
\hline \multicolumn{4}{|l|}{ Skin } \\
\hline \multirow{2}{*}{\multicolumn{4}{|c|}{ Axilla }} \\
\hline Breast & & & \\
\hline \multicolumn{4}{|l|}{ Limb } \\
\hline \multirow{2}{*}{\multicolumn{4}{|c|}{$\begin{array}{l}\text { Neck } \\
\text { Paronychia }\end{array}$}} \\
\hline & & & \\
\hline \multicolumn{4}{|l|}{ Pinna } \\
\hline \multicolumn{4}{|l|}{$\begin{array}{l}\text { Sebaceous cyst } \\
\text { Respiratory }\end{array}$} \\
\hline \multicolumn{4}{|l|}{ Tonsil } \\
\hline Quinsy & 4 & 3 & 1 \\
\hline Pleura & & & \\
\hline \multicolumn{4}{|l|}{ Miscellaneous } \\
\hline \multicolumn{4}{|l|}{ Hydrocoele } \\
\hline $\begin{array}{l}\text { Labia } \\
\text { Placenta }\end{array}$ & 4 & 3 & 1 \\
\hline Urethra & & & \\
\hline Total & 70 & 51 & 19 \\
\hline
\end{tabular}

Table 2 Isolation of anaerobes from clinical specimens

\begin{tabular}{|c|c|c|c|}
\hline \multirow[b]{2}{*}{ Isolate } & & \multicolumn{2}{|c|}{ No of isolates in: } \\
\hline & & Incubator & Jar \\
\hline Bacteroides & $\begin{array}{l}\text { fragilis } \\
\text { thetaiotaomicron } \\
\text { ovatus } \\
\text { distasonis } \\
\text { uniformis } \\
\text { vulgatus } \\
\text { bivius } \\
\text { ruminicola ss brevis } \\
\text { oralis } \\
\text { disiens } \\
\text { corrodens } \\
\text { asaccharolyticus } \\
\text { melaninogenicus ss intermedius } \\
\text { sp }\end{array}$ & $\begin{array}{r}21 \\
4 \\
4 \\
3 \\
4 \\
1 \\
9 \\
3 \\
2 \\
1 \\
36 \\
33 \\
s \\
4 \\
21\end{array}$ & $\begin{array}{r}19 \\
4 \\
4 \\
2 \\
5 \\
1 \\
8 \\
4 \\
2 \\
1 \\
34 \\
33 \\
4 \\
20\end{array}$ \\
\hline Fusobacterium & $\begin{array}{l}\text { sp } \\
\text { nucleatum } \\
\text { necrophorum } \\
\text { mortiferum } \\
\text { varium } \\
\text { sp }\end{array}$ & $\begin{array}{r}21 \\
10 \\
4 \\
1 \\
2 \\
5\end{array}$ & $\begin{array}{r}20 \\
9 \\
4 \\
1 \\
2 \\
7\end{array}$ \\
\hline \multirow{2}{*}{\multicolumn{2}{|c|}{$\begin{array}{l}\text { Veillonella parvula } \\
\text { Clostridium perfringens }\end{array}$}} & $\begin{array}{r}2 \\
25\end{array}$ & $\begin{array}{r}2 \\
24\end{array}$ \\
\hline & & $\begin{array}{l}3 \\
4\end{array}$ & $\begin{array}{r}3 \\
4\end{array}$ \\
\hline \multicolumn{2}{|c|}{ Eubacterium lentum } & 1 & 1 \\
\hline & $\begin{array}{r}1 \\
3\end{array}$ & 1 \\
\hline \multicolumn{2}{|c|}{$\begin{array}{l}\text { Peptococcus prevotii } \\
\text { asaccharolyticus }\end{array}$} & $\begin{array}{l}51 \\
15\end{array}$ & $\begin{array}{l}52 \\
18\end{array}$ \\
\hline \multicolumn{2}{|c|}{$\begin{array}{c}\text { sp } \\
\text { Pentostreptocose }\end{array}$} & $\begin{array}{l}23 \\
21 \\
22\end{array}$ & $\begin{array}{l}23 \\
22 \\
27\end{array}$ \\
\hline \multicolumn{2}{|c|}{ Anaerobic Gram-positive coccus } & 1 & 1 \\
\hline
\end{tabular}

Table 3 Colony counts and sizes in incubator (I) and jars (J)

\begin{tabular}{|c|c|c|c|c|c|c|}
\hline Organism & Date & System & $\begin{array}{l}\text { No of organisms } \\
\times 10^{9} \pm S D^{*}\end{array}$ & $p$ & $\begin{array}{l}\text { Colony size } \\
m m \pm S D \dagger\end{array}$ & $p$ \\
\hline \multirow[t]{3}{*}{$B$ fragilis } & July & $\begin{array}{l}\text { I } \\
\text { J }\end{array}$ & $\begin{array}{l}3.01 \pm 0.4 \\
2.77 \pm 0.5\end{array}$ & NS & $\begin{array}{l}2.44 \pm 0.2 \\
2.84 \pm 0.3\end{array}$ & $<0.001$ \\
\hline & Aug & I & $\begin{array}{l}1.88 \pm 0.1 \\
1.77 \pm 0.25\end{array}$ & NS & $\begin{array}{l}2.68 \pm 0 \cdot 1 \\
2.83 \pm 0.2\end{array}$ & $<0.001$ \\
\hline & Nov & I & $\begin{array}{l}2.23 \pm 0.3 \\
2 \cdot 27 \pm 0.3\end{array}$ & NS & $\begin{array}{l}2.22 \pm 0.3 \\
2.58 \pm 0.2\end{array}$ & $<0.001$ \\
\hline \multirow[t]{2}{*}{ B thetaiotaomicron } & July & I & $\begin{array}{l}1.59 \pm 0.3 \\
1.83 \pm 0.3\end{array}$ & NS & $\begin{array}{l}1.88 \pm 0.1 \\
1.9 \pm 0.2\end{array}$ & NS \\
\hline & Nov & I & $\begin{array}{l}1.99 \pm 0.4 \\
1.83 \pm 0.3\end{array}$ & NS & $1.86 \pm 0.1$ & NS \\
\hline$B$ uniformis & July & I & $2.57 \pm 0.1$ & NS & $0.9 \pm 0.1$ & $<0.001$ \\
\hline$B$ bivius & Sep & I & $\begin{array}{l}2 \cdot 57 \pm 0.2 \\
5 \cdot 98 \pm 1\end{array}$ & NS & $\begin{array}{l}1 \cdot 1 \pm 0 \cdot 1 \\
1 \cdot 51 \pm 0 \cdot 1\end{array}$ & NS \\
\hline \multirow[t]{2}{*}{$B$ corrodens } & Aug & $\begin{array}{l}\mathbf{J} \\
\mathbf{I} \\
\mathbf{J}\end{array}$ & $\begin{array}{l}6 \cdot 45 \pm 1 \\
4 \cdot 13 \pm 0 \cdot 4 \\
4 \cdot 06 \pm 0 \cdot 4\end{array}$ & NS & $\begin{array}{l}1 \cdot 46 \pm 0 \cdot 1 \\
\text { ND }\end{array}$ & \\
\hline & Nov & I & $\begin{array}{l}1.37 \pm 0.2 \\
1.41 \pm 0.2\end{array}$ & NS & $\begin{array}{l}1 \cdot 31 \pm 0 \cdot 1 \\
1 \cdot 28 \pm 0 \cdot 1\end{array}$ & NS \\
\hline \multirow[t]{2}{*}{ F nucleatum } & July & I & $\begin{array}{l}0.05 \pm 0.01 \\
0.04 \pm 0.01\end{array}$ & $<0.001$ & $\begin{array}{l}1.48 \pm 0.1 \\
2.15 \pm 0.1\end{array}$ & $<0.001$ \\
\hline & Aug & I & $\begin{array}{l}0.17 \pm 0.04 \\
0.13 \pm 0.01\end{array}$ & $<0.04$ & ND & \\
\hline$F$ mortiferum & July & I & $\begin{array}{l}1.39 \pm 0.3 \\
1.32 \pm 0.1\end{array}$ & NS & ND & \\
\hline Ps anaerobius & July & I & $\begin{array}{l}0.6 \pm 0.02 \\
0.76 \pm 0.01\end{array}$ & NS & $1 \cdot 1 \pm 0.1$ & $<0.001$ \\
\hline$P$ prevotii & Aug & I & $\begin{array}{l}0.04 \pm 0.01 \\
0.04 \pm 0.01\end{array}$ & NS & $\begin{array}{l}0.48 \pm 0.04 \\
0.66 \pm 0.03\end{array}$ & $<0.001$ \\
\hline Pracnes & July & I & $\begin{array}{l}1 \cdot 37 \pm 0 \cdot 1 \\
1 \cdot 28 \pm 0 \cdot 1\end{array}$ & $<0 \cdot 1$ & ND & \\
\hline
\end{tabular}

* Means of 8 observations.

† Means of 24 observations.

ND not done.

NS no significant difference. 
difference between colony counts only with $F$ nucleatum which on two occasions gave higher counts in the incubator.

Table 3 also shows the results of comparisons of colony size in the two systems. There was a significant difference in size in seven out of eleven tests, in each case the organisms being larger in the jar. There was no significant size difference for $B$ thetaiotaomicron (twice), for $B$ bivius and for $B$ corrodens.

Measurement of surface $\mathrm{pH}$ showed no difference between uninoculated plates from the incubator or from jars. In each case for plates having a $\mathrm{pH} 7.5$ before incubation, the $\mathrm{pH}$ rose slightly from $\mathrm{pH}$ 6.9-7 to $\mathrm{pH} 7.3$ over a period of one hour after removal. Nor were there significant differences between inoculated plates incubated in the two systems, although there was a considerable difference in $\mathrm{pH}$ for different organisms, ranging from $\mathrm{pH}$ 5.7-5.9 for $B$ fragilis to $\mathrm{pH} 7 \cdot 4-7.6$ for $V$ parvula.

Disc sensitivity tests almost invariably gave zone radii within $4 \mathrm{~mm}$ or less for both methods of incubation in 27 sets of tests on the six antibiotics, 17 of which were carried out after the incubator had been in use for six months. On only one occasion, ampicillin radii differed by $5 \mathrm{~mm}$ for an isolate of $F$ nucleatum. The application of Student's $t$ test to the two batches of sets of sensitivity tests showed no significant differences between them. On the first occasion the mean zone radii were $16.5 \mathrm{~mm}$ for the jar and $16.47 \mathrm{~mm}$ for the incubator $(\mathrm{SD}=7.8$ and $8, t=0.14 \mathrm{p}<0.99)$ and on the second radii were $19.4 \mathrm{~mm}$ and $18.8 \mathrm{~mm}(\mathrm{SD}=7.3$ and $7, t=0.46$ $\mathrm{p}<0.65)$.

\section{Discussion}

The overall results of this investigation suggest that the Planer anaerobic incubator is a suitable alternative to the jar system in terms of bacteriological performance. There were no significant differences in isolation rates of different species from clinical specimens which were chosen for their likelihood of yielding relatively fastidious anaerobes. Thus $B$ corrodens and $B$ asaccharolyticus were isolated more frequently than $B$ fragilis. The relative paucity of Gram-positive bacilli in comparison with other reported investigations ${ }^{1012}{ }^{13}$ may also be a result of this specimen selection. Nor were there, with few exceptions, differences in the counts of organisms from pure cultures (though $F$ nucleatum was more numerous in the incubator) nor in disc sensitivity tests for a variety of anaerobes with six antimicrobial agents. The fact that surface $\mathrm{pH}$ changes were similar in the two systems may well explain the similarity of performance in sensitivity tests. ${ }^{14-17}$
The only consistent difference was between colony sizes for a number of organisms, which were significantly but not much smaller in the incubator. $B$ bivius, $B$ corrodens and $B$ thetaiotaomicron were not affected in this way. We are unable to explain these findings but would comment that we saw no $\mathrm{pH}$ differences, that oxygen was probably more rapidly removed from cultures in the incubator than in jars, ${ }^{18}$ and that we saw no evidence from other investigations carried out after six months, of a build-up of toxic metabolites - and in any case, the differences were observed at all stages of the use of the incubator. It is possible that there were humidity differences, but we did not investigate this. Nor did we vary amounts of catalyst, which might have affected growth. Another possibility is that colonies were affected by the entry of oxygen via inadequate door seals, but again we did not investigate this specifically.

If the cabinet functions from a bacteriological point of view, its practicability in a diagnostic laboratory should be assessed. We worked with a prototype and clearly changes are intended as a result of our experience. Our cabinet was too deep, and we found that the entry port was too small-for example, for API-20A strips. Furthermore there was evidence that the door seals were not sufficiently gas tight, resulting in the entry of oxygen fairly rapidly into the entry port, and more slowly into the chamber when its atmosphere was not recharged by use. We also found the turntable and transfer arm system wasteful of space and would prefer shelves and two glove ports instead. If these changes were made, we feel that the cabinet would be useful in a diagnostic laboratory. The advent of anaerobic work stations does not change this decision as we feel that if plates can be examined without removing them from the incubator, all other manoeuvres for identification and sensitivity testing can be carried out on the open bench, provided cultures are returned promptly to an anaerobic chamber. This is satisfactory for the jar system and should be equally satisfactory for the incubator, which would be an attractive option if it were less expensive than a work station.

We are grateful to the DHSS for a grant towards this work and for the provision of the incubator.

\section{References}

' Dowell VR. Comparison of techniques for isolation and identification of anaerobic bacteria. Am J Clin Nutrit 1972;25:1335-43.

${ }^{2}$ Killgore GE, Starr SE, Del Bene VE, Whaley DN, Dowell VR. Comparisons of three anaerobic systems for the isolation of 
anaerobic bacteria from clinical specimens. Am J Clin Pathol 1973;59:552-9.

${ }^{3}$ Wren MWD, Baldwin AWF, Eldon CP, Sanderson PJ. The anaerobic culture of clinical specimens: a 14-month study. $J$ Med Microbiol 1977;10:49-61.

4 McMinn MT, Crawford JJ. Recovery of anaerobic microorganisms from clinical specimens in prereduced media versus recovery by routine clinical laboratory methods. Appl Microbiol 1970;19:207-13.

${ }^{s}$ Rosenblatt JE, Fallon A, Finegold SM. Comparison of methods for isolation of anaerobic bacteria from clinical specimens. Appl Microbiol 1973;25:77-85.

- Morgan JR, Smith JA, Liu P. Improving the performance of anaerobic bacteriology in a hospital laboratory. J Clin Pathol 1977;30:157-9.

${ }^{7}$ Gargan RA, Phillips I. Performance of converted pressure cookers and two conventional jars for anaerobic bacterial culture. $J$ Clin Pathol 1978;31:426-9.

${ }^{8}$ Brewer JH, Allgeier DL. Safe self-contained carbon dioxidehydrogen anaerobic system. Appl Microbiol 1966;14:985-8.

${ }^{9}$ Myers MB, Cherry G, Bernside BB, Bernside GH. Ultraviolet red fluorescence of Bacteriodes melaninogenicus. Appl Microbiol 1969;17:760-2.

${ }^{10}$ Phillips I, Taylor E, Eykyn S. The rapid diagnosis of anaerobic infection. Infection (suppl 2) 1980;8:155-8.

"Holdeman LV, Cato EP, Moore WEC. Anaerobe laboratory manual. 4th ed. Virginia Polytechnic Institute and State University Anaerobe Laboratory, 1977.

${ }^{12}$ Moore WEC, Cato EP, Holdeman LV. Anaerobic bacteria of the gastrointestinal flora and their occurrence in clinical infections. J Infect Dis 1969;119:641-9.

${ }^{13}$ Martin WJ. Isolation and identification of anaerobic bacteria in the clinical laboratory-a two-year experience. Mayo Clin Proc 1974;49:300-8.

14 Ingham HR, Selkon JB, Codd AA, Hale JH. The effects of carbon dioxide on the sensitivity of Bacteroides fragilis to certain antibiotics in vitro. J Clin Pathol 1970;23:254-8.

15 Watt B, Brown FV. Sensitivity testing of anaerobes on solid media. J Antimicrob Chemother 1975;1:440-2.

${ }^{16}$ Phillips I, Warren C. Susceptibility of Bacteroides fragilis to spectinomycin. J Antimicrob Chemother 1975;1:91-5.

${ }^{17}$ Watt B, Hoare MV, Collee JG. Some variables affecting the recovery of anaerobic bacteria: a quantitative study. J Gen Microbiol 1973;77:447-54.

${ }^{18}$ Ferguson IR, Phillips KD, Willis AT. An evaluation of the "GasKit" disposable hydrogen and carbon dioxide generator for the culture of anaerobic bacteria. J Appl Bacteriol 1976;41:433-7.

Requests for reprints to: Professor Ian Phillips, Department of Microbiology, St Thomas's Hospital Medical School, London SE1 7EH, England. 